\title{
“WE DON'T NEED TO BE CURED FIRST IN ORDER TO LIVE": Self-help in OAXaCa, MeXico (An Account of an Interview with German Perez Cruz)
}

\author{
Brigitte Holzer
}

Acceso Libre - Free Access - was the name chosen for itself ten years ago by a group of twenty people with various physical disabilities. The name symbolises the group's political goals: Free Access makes entry possible for anyone who wants it. This is the vision with which the organisation's members, people with impaired mobility and wheelchair users, confront the public: a vision of being able to move freely everywhere, and go wherever they want. This meant changing the concrete physical conditions in their environment, and so the members started by calling for ramps to be built in the municipal area and introduced in public buildings. Their work was rewarded: public buildings and each pavement, street or square that was built or repaired got a ramp. A further goal pursued by the association's members is equal access and rights on all levels of social existence, as equal members of society. Today, Acceso Libre is a centre which supports the training of young people with disabilities - of whatever kind - and above all, aims at developing awareness: members of society need to learn to be aware of disabled people's abilities, disabled people have to learn to believe in themselves, and their parents have to be prepared to learn with them. Each one of these concerns reveals that the inclusion of people with disabilities in social life is not self-evident.

\section{LIVING IN DEPENDENCE}

G. Perez Cruz uses his own biography as point of departure to illustrate the complexity of the mechanisms which combine to prevent disabled people from feeling they are full and equal members of society. At the age of six months he got polio, which mainly affected his left leg. 
Soon a period of rehabilitation began, which was very stressful for me. Until I was 18 , I was continually travelling to Mexico City with my mother in search of a cure. These journeys had consequences which I only began to assess as an adult. If I had an appointment with a doctor, I never knew beforehand if I would be coming home after one week or four. Sometimes I went to Mexico City and a doctor did nothing more than examine and measure the leg. For this though I would have missed school yet again, and in the end I had lost two years of school. In Mexico City I had a successful operation - at least I can walk now - but it's a hard thing to look back at the end of your youth and come to the conclusion that you haven't developed your own line, you have never structured your own life. Your whole life plan was dependent on outsiders, strangers you didn't know and would never see again. Then, when you're older, your family expects you to give your life some direction, to work or take exams, to go to university. But how could I suddenly take my own life in hand, when it had always been in other people's hands before? They had taken all the decisions in my life, they defined and occupied my spaces, they never gave me what I had needed most from early childhood on: selfconfidence and courage. This was a hard thing to take on board. I began to drink.

In a sports club for people with disabilities, G. Perez Cruz met others in the same position. They were unanimous: "Something isn't functioning right in our society. Why should we be cured? Why don't we start much earlier taking opportunities to adapt our lives and their conditions to each other?”

The group of young people began developing their own concept of disability, one which was to become the basis for Acceso Libre's work: if society does not know how to fulfill someone's needs because it does not understand them, it labels that person disabled. Disability itself is seen as a problem, instead of the external conditions which are not (yet) adapted to the needs of the disabled person. When a ramp is installed, people assume they have solved a problem for the disabled. They don't see that one of many needs has been met. The thinking of the parents reflects this social structure. They bring their child to the doctor with the attitude: "All will be well if our child gets better." The disability however is there and stays there; and the parents' position does nothing to alter the conditions in whose light the disability appears as a problem. The consequences of this are incurable.

The members of Acceso Libre perceive a great responsibility for people with disabilities. They say to disabled youngsters and their parents: 
We don't need to be cured in order to live. What we need to do is make our needs known. The parents must accept the disability, not fight against it, and open up the right paths for the child so that it arrives at the point where the disability presents the least hindrance. If the child can develop her or his own way of living, the society will learn to understand it and provide the necessary tools.

In terms of the work done at the centre, this means confronting the indifference and passivity so often found in people with disability, precisely because they are never given any responsibility. Their lives seem to be organised by professionals and parents. They get used to being dependent. Many, for example, come and want to do training, want to learn something (new), but do not see that this requires engagement and effort. This attitude is also reflected in the way Acceso Libre is treated.

People are always trying to use us as a commercial service provider. They won't see that the centre's very existence revolves around disabled people taking their own lives in hand, and that our work in the centre has to be supported in order to change the social conditions of life with a disability. People have got used to being dependent, and that makes it difficult to create something new.

Acceso Libre lays down clear conditions for those who come to the centre.

If you want to learn something, you must learn. If you come here because you don't know where else to go, no-one will take any interest in you. The centre isn't a place just to go to and be at, it's a place where you make something of yourself. Your place is out there in society, where you will be confronted with problems which you will solve, slowly but surely.

Parents are integrated into the young people's training. When they visit the centre in search of training for their children, they have to promise their cooperation. They support the concrete organisational work and learning, not standing over their children, but at their sides. Acceso Libre does not levy any membership fees.

Fees create rights and undermine responsibility. No-one must be able to say, Why should I keep working for them, after all, I pay them regularly. 


\section{LIVING INDEPENDENTLY}

Being able to lead an independent, self-determined life seems to be a common, central goal of self-help movements in many countries. Yet with regard to precisely this goal it becomes clear just how much the meaning of a vision which, on the surface, everyone seems to share, changes according to cultural context. In the conversation with G. Perez Cruz, being able to take responsibility for oneself and others emerges as the most significant feature characterising what is understood by 'an independent life' in Oaxaca. The fact that the life of the individual there is strongly linked to the family plays an important role in this.

Each member of the family does something that can contribute to the family staying together as a social unit. Particular attention is paid to the mother, because she and the house she lives in are the centre of the small community. A disabled member of the family almost always sees her or himself as a person who cannot contribute to the family's livelihood. This is what creates the acute sense of total dependence. At this point the person with the disability experiences him or herself as unequal and different.

Being able to lead a self-reliant and independent life does not imply managing without the family, but rather becoming a member of the family. Part of this consists in the person with the disability becoming aware of his or her own needs and learning to satisfy them.

If I need an orthopaedic apparatus in order to walk, I don't wait until someone gives it to me and use an amulet while waiting, instead I know my needs and know how to satisfy them.

G. Perez Cruz gives the example of a young man from a small village whose father brought him to the centre with the words, "I don't know what to do with him any more." The son had injured his spine and was partly paralysed. We worked with him at the centre, and slowly but surely the young fellow began to grow. He developed a personality. Three years ago he left the centre, because he had found two jobs. His sister, whom he lived with during his time at the centre, recently lost her husband in an accident, and is now being supported by her brother. He's getting married soon, I don't know how he does it, because actually he never has any time. 


\section{The Work of the Centre}

The centre Acceso Libre is the point of departure for many varied activities related to work for and with people with disabilities. The centre occupies a rented house and has several full-time coordinators for various areas of activity: PR, training, schooling, workshops, rehabilitation, parent participation, training teachers for integrated education, project development, etc. In the centre itself classes and training units aimed at providing a transition to normal schools/places of work are organised. The teaching is based on the principle of interactive learning (the participants teach each other), which means less spending on resources (teachers). In November 1998 the centre coordinated the first Forum of Latin American Women with Disabilities, attended by 40 women from eight different countries.

An increasingly important area of the centre's work are the Centros de Recursos, which workers at the centre hope to establish and coordinate in rural areas. The problem for people with disabilities in rural areas is different from in the city. On the one hand, the communities protect their thickies (El Loquiito), their gammy leg (El Cojito). On the other they often isolate them as well. They are frequently not given any functions and so cannot relate to others, and have no personal relationships.

Once people are in the position to fill a place, doors are opened to them. The most important resource that our work in the centre mobilises in the people affected is self-confidence. They get to know their needs and how to meet them. Back in their villages this is in fact what is so important: conveying what they know about their special needs.

\section{Money Should Not Be the Problem}

Acceso Libre wants to work with universities to facilitate studies of material, ecological and social basics. The results would then be used as guidelines to establish what kind of production centre or other amalgamation would be meaningful for securing livelihoods.

When we want to start any kind of activity, we always come up against the problem that people think of the money which appears to be necessary and is mostly not available. There are so many resources, particularly in rural areas, which must be intelligently mobilised. The activities are not first and foremost a question of money. We don't 
need a computer or a typewriter for a rural centre. We need the support of people. Young people often have time to spare; one could get them interested in the interactive learning, for example. Recently someone donated us a site for a rehabilitation centre 20 metres from a beautiful lagoon. It would be possible to negotiate with the communities. Give us this or that, and we will keep the park in the centre in order.

The self-help centre in Oaxaca City itself provides a secure and more or less well-paid job for many people with disabilities. At present though, the workers are finding out the hard way how long and how well it can keep going without regular financial support. From March to September they have to go without the Kellogg Foundation's donation. 